\title{
The Effects of Managerial Ownership, Institutional Ownership, and Profitability on Capital Structure: Firm Size as the Moderating Variable
}

\author{
Muhammad Khafid ${ }^{1}$, Rida Prihatni ${ }^{2} \&$ Ira Eva Safitri $^{1}$ \\ ${ }^{1}$ Universitas Negeri Semarang, Indonesia \\ ${ }^{2}$ Universitas Negeri Jakarta, Indonesia \\ Correspondence: Muhammad Khafid, Universitas Negeri Semarang, Indonesia.
}

Received: April 7, 2020

Accepted: May 21, 2020

Online Published: July 8, 2020

doi:10.5430/ijfr.v11n4p493

URL: https://doi.org/10.5430/ijfr.v11n4p493

\begin{abstract}
This study was to analyze the effects of managerial ownership, institutional ownership, and profitability on capital strucuture with firm size as the moderating variable. All manufacturing companies of basic industry and chemical sector listed on Indonesia Stock Exchange during the period of 2014-2017 were the population of the study. There were 66 taken as the samples by using purposive sampling technique. There were 39 companies as research samples and 115 as unit of analysis. Data were collected by documentation method. Then, data were analyzed by using descriptive statistics and inferential statistics. The results of the study indicated that managerial ownership and institutional ownership did not significantly affect capital structure, but profitability had a negative and significant effect on capital structure. Firm size did not have any moderating effect between managerial ownership and profitability on capital strucuture, but firm size moderated the effect between institutional ownership and capital structure. It was concluded that only profitability significantly influenced capital structure, and firm size was able to moderate the effect between institutional ownership and capital structure.
\end{abstract}

Keywords: institutional ownership, managerial ownership, profitability, capital structure, firm size

\section{Introduction}

A company was established with various objectives. The main goal desired by the company was to bring prosperity for the owners of the company. The company was expected to operate in the long run with the increasing profits. What the company really needs to achieve its goals was the funding source. The optimal capital structure was the company's goal to decide funding policy by considering several items.

Optimizing the capital structure could be achieved when the company's stock price reaches the maximum value which was the result of a combination of debt and equity of the company (Bringham \& Houston, 2014). The act of choosing between risk and the expected rate of return was a capital structure policy. The company raises the risk level of the company's revenue stream by adding debt, on the other hand the high debt would increase the expected return. The purpose of establishing a capital structure was to increase the company's stock price, which was then expected to improve the welfwere of the company owners.

The Indonesian Stock Exchange (IDX) Fact Book showed that basic and chemical industry companies were one of the sub-sector companies having a relatively high DER ratio, although it has decreased for several years, even in 2016 it dropped to -1.75 , but in 2017 the DER ratio again experienced a significant increase to 1.62. This ratio implies that most capital companies in basic and chemical industries still rely on external parties. One of the basic industrial and chemical companies that were experiencing financial problems causing a decline in shwere prices was PT JKSW Tbk. PT JKSW Tbk for four years in a row (2014-2017) has a negative DER value, which was $-1.73 ;-1,60$; -1.62; and -1.55. It was further strengthened by the news reported by Bisnis.com on May 11, 2018 which stated that PT Jakarta Kyoei Steel Works Tbk was included in the Indonesia Stock Exchange's top trading losers. PT Jakarta Kyoei Steel Works Tbk. fell for $17.71 \%$ and ended at Rp 79 per share. This news further proved that until 2018 PT JKSW was also still experiencing financial problems.

The facts above showed that the determination of the company's capital structure policy should be considered more thoroughly. Debt to Equity Ratio (DER) value which was getting smaller or below zero (0) indicating that the company's equity had a deficit, so the company usually sold some of its assets to meet its capital needs. Companies 
which had a negative DER value were likely to suffer losses resulting in the company's equity to be minus. Capital structure decisions made inadvertently could lead to bankruptcy for the company.

Some determinants of a company's capital structure were managerial ownership, institutional ownership, and profitability. The results of previous studies on the three factors above still hadinconsistent results. A study done by Arslan (2008), Wahba (2014) and Wellalage \& Locke (2015) produced a fact that managerial ownership and capital structure had a negative and significant relationship. On the other hand, Shoaib \& Yasushi (2015) found a positive relationship between these two variables. However, Brailsford et al. (2002) found that there was not any relationship between the two variables.

Pirzada (2015) found that there was not any relationship between institutional ownership and capital structure variables. Roshan et al. (2009), Hammerstrom \& Jersov (2014) and Cinko \& Kasaboglu (2017) found a negative relationship between these two variables. However, Brailsford et al. (2002) and Qiang (2007) showed the different results, positive and significant relationship. Gomez et al. (2014) found the fact that profitability had a negative and significant effect on capital structure variable. This finding was further strengthened by Cortez \& Susanto (2012), Ashraf \& Rasool (2013) and Pratheepan \& Yatiwella (2016)'s findings. However, Ross (1977), Frank \& Goyal (2003), Baum et al. (2007) and Wellalage \& Locke (2015) found that there was a positive and significant effect between the two variables.

The purpose of this study was to find the empirical evidence of the effects of managerial ownership, institutional ownership, and profitability on capital structure with the moderating variables of firm size. The novelties of the study were using data from 2014 up to 2017, and adding firm size an moderating variable supposed to be able to influence both as a reinforcer and a weaker. The selection of moderating variables was based on the results of previous studies that have shown consistency of results, including research done by Saksonova (2006), Kim \& Suh (2010), Wellalage \& Locke (2013), Gwatidzo (2013) and Zwere et al. (2013) who found that there was a positive and significant relationship.

\section{Literature Review}

Agency theory, pecking order theory, and signal theory were used in the study. Agency theory was a theory of agency relationships. Agency relationship was a relationship between the owner of the company with the manager of the company where the company manager was a representative of the owner of the company to run the company. On the other hand, this agency relationship also triggered agency conflicts that occur between the two. This agency conflict raises agency costs. Managerial ownership and institutional ownership were the alternatives used to reduce agency costs. Institutional ownership was expected to reduce the debt function within the company, so it made the company's capital structure relatively low.

Pecking order theory suggested a company funding hierarchy (Myers, 1984). This theory brought two different thoughts, first the source of funding the company prefers was the source of internal funding (retained earnings). This selection was based on the consideration of not giving rise to negative signals which were feared to make the company's stock price lower. Second, if the company suffers from lack of funds, the first thing to do was the issuance of debt, while the issuance of new shares was the last alternative. Companies with high retained earnings would keep the company's capital structure relatively low because their retained earnings were able to cover the company's operating costs so only require a relatively low level of debt.

Signaling theory explained that information held by the executive would be conveyed to outside parties to attract potential investors to raise the company's stock price. A positive signal from a company executive would attract investors to invest in the company. The high shareholder investment was used by companies as financing capital, , so that debt was relatively low and capital structure was also directly proportional to debt.

Agency costs were caused by conflicts arisen over the agency relationship. One alternative offered by Jensen \& Meckling (1976) to reduce agency costs was by applying managerial ownership. Managerial ownership of the company was expected to decrease the agency conflicts because management ownership shows that the company was owned by the management of the company itself (Khafid et al., 2019). On the other hand, managerial ownership was intended to tighten the supervision of managers in making funding decisions and to reduce agency conflicts between managers and owners (Wellalage \& Locke, 2015). Expectations of this high profit encourage shareholders to prefer projects having high risks. However, there was a view that the risk caused by undiversified debt was greater felt by management than outside investors (Bringham \& Houston, 2014). Managerial ownership could help managers in making decisions in order to keep the company's debt levels remain low, it was an advantage for the company manager who was also the owner of the company. Therefore, high managerial ownership would have an impact on 
the company's low debt. It was in line with the results of the study done by Arslan (2008), Wahba (2014) Wellalage \& Locke (2015), and Hayat et al. (2018) who discovered the negative relationship between managerial ownership and capital structure.

\section{$H_{1}$ : Managerial ownership has a negative and significant effect on capital structure}

An alternative to lowering the next DER was with institutional ownership. Institutional ownership was intended to oversee manager performance. Agency theory predicts reducing agency problems could be done with the strength of institutional ownership that was expected to replace the role of debt as a management monitor (Short et al., 2002). This statement was further strengthened by Jensen \& Meckling (1976) which suggested an alternative in reducing debt was a high and effective institutional ownership which was expected to be able to take over the role of debt. In line with the statement, Joher et al. (2006), Roshan et al. (2009), Hammerstrom \& Jersov (2014) and Cinko \& Kasaboglu (2017) showed that institutional ownership was able to have a negative and significant effect on capital structure.

\section{$\mathrm{H}_{2}$ : Institutional ownership has a negative and significant effect on capital structure}

The high profitability of the company indirectly decreases the capital needs of outsiders, because every profit earned by the company from its production activities would increase the company's assets and could be used to pay corporate liabilities, so that dependence on outsiders would be reduced (Khafid et al., 2019). The retained earnings they obtain would be able to cover the company's operational funding both in large part and in full. Signaling theory explained that the presence of a positive signal from company executives would be expected to increase the interest of outsiders to buy company shares, so the level of corporate debt would tend to be relatively low. Then, the pecking order theory revealed the company's partiality on internal funding rather than external funding. The high retained earnings determined by the company would have an effect on the low level of corporate debt. This hypothesis was in line with Cortez \& Susanto (2012), Ashraf \& Rasool (2013), Gomez et al. (2014), and Pratheepan \& Yatiwella (2016)'s findings that found that there was a negative relationship between profitability and the company's capital structure.

\section{$\mathrm{H}_{3}$ : profitability has a negative and significant effect on capital structure.}

In accordance with agency theory, companies use managerial to reduce agency costs that arise. The higher managerial ownership, the tighter the control of managerial behavior in funding decision making. But on the other hand, the large firm size further increases the company's operating capital. Signaling theory explained that firm size was able to generate a positive signal to external parties that the company has been able to develop well in the midst of business competition (Ross, 1977). Firm size would also trigger a higher level of corporate debt (Chen \& Strange, 2005). It was in line with the findings of Saksonova (2006), Kim \& Suh (2010), Wellalage \& Locke (2013), Gwatidzo (2013) and Zwere et al. (2013) that stated, firm size was also followed by the high capital structure of the company. Therefore, firm size would weaken or increasingly have a positive influence on the relationship between managerial ownership and capital structure. Vice versa, the small firm size would further strengthen or negatively influence the relationship between managerial ownership and capital structure. It was based on the low size of the company unable to provide trust in creditors to provide debt.

\section{$\mathbf{H}_{4}$ : Firm size significantly moderates the effect of managerial ownership on capital structure.}

Agency theory explained that institutional ownership was expected to replace debt in reducing agency costs. Firm size resulted in an increasingly large need for external funds (Wellalage \& Locke, 2013). It was because the larger the company, the more complex its activities, so it requires more external funds. Signaling theory explained that firm size was able to generate a positive signal to external parties that the company has been able to develop well in the midst of business competition (Ross, 1977). Firm size would also trigger a higher level of corporate debt. This hypothesis was in line with by Saksonova (2006), Kim \& Suh (2010), Wellalage \& Locke (2013), Gwatidzo (2013) and Zwere et al. (2013) findings which found the large firm size in line with the increasing capital structure of the company. Therefore, firm size would weaken or increasingly had a positive effect on the relationship between managerial ownership and capital structure. Vice versa, the small firm size would further strengthen or negatively influence the relationship between managerial ownership and capital structure. It was based on the low size of the company which was unable to provide trust in creditors to provide debt.

\section{$\mathrm{H}_{5}$ : Firm size moderates the effect of institutional ownership on capital structure.}

Signal theory explained that the presence of a positive signal from company executives was expected to be able to generate interest from outside parties to invest shares in the company, , so that the level of company debt was relatively low. Pecking order theory revealed that in operational funding compared with extrenal funding, companies 
prefer internal funding. Firm size would also increase the need for company operational funds. Firm size would attract outside trust. Therefore, firm size would be followed by a high level of debt to meet the operational funding needs. This hypothesis was in line with by Saksonova (2006), Kim \& Suh (2010), Wellalage \& Locke (2013), Gwatidzo (2013) and Zwere et al. (2013) findings that find a direct proportion between firm size with the company's capital structure. Therefore, firm size would weaken or increasingly have a positive influence on the relationship between institutional ownership and capital structure. Vice versa, the small firm size would further strengthen or negatively influence the relationship between institutional ownership with capital structure. It was based on the low size of the company unable to provide trust in creditors to provide debt.

\section{$\mathrm{H}_{6}$ : Firm size moderates the effect of profitability on capital structure.}

\section{Methods}

It was a quantitative study with secondary annual report data and accessed through the IDX website. The population of this research were 66 industrial and basic industrial companies listed on the Indonesia Stock Exchange 2014-2017. The sample selection was based on a list of companies listed on the Indonesia Stock Exchange in 2014-2017, this sector was one sector having a relatively high capital structure value and in 2016, there was a sharp decline while in 2017 experienced a significant increase in capital structure, then products from this company were needed by all levels of society, so that the company required no small amount of funds. The sample of this study used a purposive sampling method, there were 39 companies with 115 units of analysis. This unit of analysis reduced outlier data by 41 data. The detection of outliers was done by determining the limit value that was equal to 3 . The unit of analysis data was declared outlier if the $\mathrm{z}$-score value of variable data was more than 3 and less than $-3(-3<\mathrm{x}<3)$, where $\mathrm{x}$ was the z-score value of data unit of analysis. The details of sample selection could be seen in Table 1 .

Table 1. The research samples

\begin{tabular}{llc}
\hline \multicolumn{1}{c}{ Sample Criteria } & Not in Criteria & $\begin{array}{c}\text { In } \\
\text { Criteria }\end{array}$ \\
\hline a. $\quad \begin{array}{l}\text { Basic and chemical industrial companies listed on the Indonesia Stock } \\
\text { Exchange in the 2014-2017 period }\end{array}$ & 66 \\
b. Companies that consistently publish annual reports for the 2014-2017 & $(14)$ & 52 \\
$\quad$ period & & \\
c. Companies with rupiah units & $(13)$ & 39 \\
d. Observation Year & & 4 \\
Number of Samples & 39 \\
Number of research analysis units (4 years x 3 companies) & 156 \\
Outlier data during the observation year & & 41 \\
Number of research analysis units in 2014-2017 & 115 \\
\hline
\end{tabular}

Source: The processed secondary data, 2018

The explanation of this research presented in Table 2. 
Table 2. Operational definitions of research variables

\begin{tabular}{|c|c|c|c|}
\hline No & Variables & Definitions & Indicators \\
\hline 1 & $\begin{array}{l}\text { Capital Structure } \\
\text { (DER) }\end{array}$ & $\begin{array}{l}\text { Comparison between the amount of } \\
\text { long-term debt with company equity } \\
\text { (Hirdinis, 2019). }\end{array}$ & $\begin{array}{l}\text { DER: } \frac{\text { total debt }}{\text { total equity }} \\
\text { (Hirdinis, 2019) }\end{array}$ \\
\hline 2 & $\begin{array}{l}\text { Managerial } \\
\text { Ownership (MO) }\end{array}$ & $\begin{array}{l}\text { The proportion of company owners owned } \\
\text { by management who act actively in the } \\
\text { company (Chou, 2015) }\end{array}$ & MO: $\frac{\text { number of insider shares }}{\text { Total shares outstanding }}$ \\
\hline & & & (Chou, 2015) \\
\hline 3 & $\begin{array}{l}\text { Institusional } \\
\text { Ownership (IO) }\end{array}$ & $\begin{array}{l}\text { Ownership of shares by institutional } \\
\text { investors (financial institutions, legal entity } \\
\text { institutions, and other institutions) (Chung \& } \\
\text { Zhang, 2009) }\end{array}$ & $\begin{array}{c}\text { IO: } \frac{\text { Number of institutional shares }}{\text { total shares outstanding }} \\
\text { (Cinko \& Kasaboglu, 2017) }\end{array}$ \\
\hline 4 & Profitability (ROA) & $\begin{array}{l}\text { The ability of the company to generate } \\
\text { profits in a certain period (Tailab, 2014). }\end{array}$ & $\begin{array}{c}\text { ROA: } \frac{\text { Profit after tax }}{\text { total aset }} \\
\text { (Tailab, 2014) }\end{array}$ \\
\hline 5 & $\begin{array}{l}\text { The firm size } \\
\text { (SIZE) }\end{array}$ & $\begin{array}{l}\text { A description of firm size (Wellalage \& } \\
\text { Locke, 2013). }\end{array}$ & $\begin{array}{c}\text { Ln Tota Asset } \\
\text { (Hartoyo, Khafid, \& Agustina, 2014) }\end{array}$ \\
\hline
\end{tabular}

Data were collected by the documentation method in the form of annual report. The research model was analyzed by testing the absolute difference value. The regression equation using the absolute difference could be seen below:

$$
\mathrm{DER}=\alpha+\beta 1 \mathrm{KM}+\beta 2 \mathrm{KI}+\beta 3 \mathrm{PROF}+\beta 4|\mathrm{KM}-\mathrm{SIZE}|+\beta 5|\mathrm{KI}-\mathrm{SIZE}|+\beta 6|\mathrm{PROF}-\mathrm{SIZE}|+\mathrm{e}
$$

The moderating regression hypothesis was performed by using Moderated Regression Analysis (MRA). The effect of moderating or hypothesis was accepted if it had a significance value was less than 0.05 .

\section{Result}

Descriptive statistics were used to describe individual variables including the maximum, minimum, mean, and standard deviation values. The results of the descriptive analysis were presented in Table 3.

Table 3. Descriptive statistics analysis results

\begin{tabular}{lccccc}
\hline & $\mathrm{N}$ & Minimum & Maximum & Mean & Std. Deviation \\
\hline DER & 115 & 0.00780 & 3.40814 & 0.9692296 & 0.77704654 \\
KM & 115 & 0.00000 & 0.35170 & 0.0317510 & 0.06929470 \\
KI & 115 & 0.00018 & 0.97212 & 0.4997940 & 0.28040198 \\
ROA & 115 & -0.10733 & 0.18260 & 0.0395551 & 0.06049040 \\
SIZE & 115 & 25.64050 & 31.52210 & 28.2457723 & 1.48780091 \\
Valid N (listwise) & 115 & & & & \\
\hline
\end{tabular}

Sumber: Output SPSS, 2019.

The descriptive statistical analysis results in Table 3 showed that the DER, KI, and SIZE variables had a fairly good data distribution. The results of statistical tests show that the average value of the capital structure during the observation year was quite good at 0.99 . The average managerial ownership was still quite low at 0.03 . Then, the average, institutional ownership was also relatively low but higher when compared to managerial ownership, which 
was 0.49 . The average profitability of the sample companies also shows that they were still quite low at 0.04 . Whereas the average size of the company shows a relatively high number of 28.24.

The Kolmogorov-Smirnov (K-S) results showed a significance of $0.064>0.05$, so that the residual data were normally distributed. Multicollinearity test shows VIF value $<10$ and tolerance value $>0.01$ which means no multicollinearity symptoms were detected. The autocorrelation test was performed using the Durbin-Watson Test which obtained a DW value of 2.024. DW value was between the $\mathrm{dU}$ and 4-dU values, where the dU value $=1.768$ while the $4-\mathrm{dU}$ value $=2.232(1.768<2.024<2.232)$, so that there was no autocorrelation. Finally heterokesdatisitas use park test, where the results indicate that the significance value> 0.05 , so that symptoms of heteroscedasticity do not occur. Based on testing the hypothesis, the regression equation could be written as follows:

$$
\text { DER }=1,109-0,313 \mathrm{KM}+0,059 \mathrm{KI}-0,312 \mathrm{ROA}+0,115 \text { |KM-SIZE| - 0,178 |KI-SIZE| - 0,108 |ROA-SIZE| }
$$

The adjusted $\mathrm{R}$ squwere value was 0.191 , it means that $19.1 \%$ of capital structure variations could be explained by the model in this study, while $80.9 \%$ was explained by other independent variables. The results of hypothesis testing could be seen in Table 4 .

Table 4. The hypothesis testings

\begin{tabular}{llrrr}
\hline Hypothesis & $\beta$ & $\mathrm{Sig}$ & Result \\
\hline 1. $\quad \begin{array}{l}\text { Managerial ownership has a negative and significant effect } \\
\text { on capital structure. }\end{array}$ & -0.313 & 0.155 & $\mathrm{H}_{1}$ Rejected \\
2. $\quad \begin{array}{l}\text { Institutional ownership has a negative and significant effect } \\
\text { on capital structure. }\end{array}$ & 0.059 & 0.391 & $\mathrm{H}_{2}$ Rejected \\
3. $\quad \begin{array}{l}\text { Profitability has a negative and significant effect on capital } \\
\text { structure. }\end{array}$ & -0.312 & 0.000 & $\mathrm{H}_{3}$ Accepted \\
4. $\quad \begin{array}{l}\text { Firm size moderates the effect of managerial ownership on } \\
\text { capital structure }\end{array}$ & 0.115 & 0.578 & $\mathrm{H}_{4}$ Rejected \\
5. $\quad \begin{array}{l}\text { Firm size moderates the effect of institutional ownership on } \\
\text { capital structure }\end{array}$ & -0.178 & 0.040 & $\mathrm{H}_{5}$ Accepted \\
6. $\quad \begin{array}{l}\text { Firm size moderates the effect of profitability on capital } \\
\text { structure. }\end{array}$ & -0.108 & 0.632 & $\mathrm{H}_{6}$ Rejected
\end{tabular}

Source: The processed secondary data, 2019

\section{Discussion}

There was not any effect of managerial ownership on capital structure. The non-effect of this independent variable happened because most of the basic and chemical industrial companies had managerial ownership below the average seen in table 3. In general the sample companies have relatively small managerial ownership, so that they require more supervision funds. To overcome this, the company could do debt. Therefore, managers do not use managerial ownership as a baswas for consideration of determining capital structure policies. The incompatibility of this research with agency theory was to reduce agency costs, so one alternative used was to increase managerial ownership of the company. But on the other hand, it was in line with the findings of Brailsford et al. (2002), Pindado \& Torre (2011), and Purba \& Africa (2019).

There was not any relationship between institutional ownership and capital structure. The independent variable did not affect the dependent variable could be observed in table 3, presumably because the average institutional ownership was quite high at 0.4998 . The average sample company has an above-average institutional ownership level of $73 \%$. Researchers suspect that institutional ownership was less effective in replacing debt in overseeing managers. Most institutional shareholders were passive shareholders where they rarely attend the RUPS held by the company, so that institutional shareholders cannot provide maximum supervision to managers. Therefore, the high institutional ownership was not able to replace debt as a supervisor manager. The high institutional ownership was not used as a manager as a baswas for consideration of determining capital structure. This finding was not in line with agency theory (Agency Theory) which states that the strength of institutional ownership was expected to replace the role of debt in overseeing management, so that agency problems would be reduced (Short et al., 2002). The 
results of this study were in accordance with Shyu (2013), Pirzada et al. (2015) and Purba \& Africa (2019)'s findings.

Profitability was proven to be able to have a negative and significant effect on capital structure. In accordance with the funding hierarchy, the pecking order theory, when a company to meet the funding shortage, it would close it by conducting debt before going through equity or issuing company shares if the company's internal funding was not sufficient. It was done because the sacrifice of the cost of issuing company shares was higher when compared to the interest costs caused by debt. This finding was in line with Cortez \& Susanto (2012), Ashraf \& Rasool (2013), Gomez et al. (2014), and Pratheepan \& Yatiwella (2016)'s findings.

Firm size did not give managerial ownership influence on capital structure. This finding explained that managerial ownership moderated by firm size was not able to predict the behavior of capital structure variables. This inability was suspected because managers do not only focus on the interests of shareholders. Managerial ownership did not affect the manager's decision to increase debt. Even though firm size was getting bigger, the manager's decision to keep the low debt level was not easily influenced. It was because the risk caused by undiversified debt could increase the firm's risk and also greater for managers than for outside investors (Bringham \& Houston, 2014).

Firm size was proven to influence institutional ownership on capital structure. These results could be observed in Table 4 that the presence of firm size increasingly gives a negative influence on institutional ownership on capital structure or strengthens the relationship between the two. Referring to agency theory, which predicts that companies reduce agency problems with the strength of institutional ownership that was expected to replace debt to oversee management performance (Short et al., 2002). Institutional shareholders were considered as more professional parties in supervising the performance of managers. The larger firm size, the more operational activity that causes greater costs. On the other hand, large companies were also interested in maximizing the assets they have to meet operational funding when compared through external funding. Therefore, firm size was able to strengthen the effect of institutional ownership on the company's capital structure.

Firm size was not able to give effect between profitability and capital structure. It was allegedly because it was unable to provide strong guarantees to creditors to provide debt. This inability to provide strong collateral was possible because creditors not only use firm size as a consideration for granting debt, but also pay attention to profitability level of the company. For example; PT DPNS Tbk in 2015 and 2016. Declining profitability of the company was followed by a decrease in the ratio of the company's capital structure, i.e. profitability level was 0.0359 with capital structure of the company was 0.1357 whereas when profitability level was 0.0338 with company's capital structure was 0.1248. On the other hand, firm size PT Duta Pertiwi Tbk has increased from 26.33381 to 26.4141. Although firm size was increasing, there was not any effects on the relationship between profitability and the company's capital structure.

\section{Conclusion}

Based on the results and discussion, it could be concluded that the high profitability of the company's capital structure would be lower. Then, firm size was able to exert a negative influence on institutional ownership on capital structure. The high profitability of the company was expected to attract investors to invest their shares, so that the company's debt ratio tends to remain low. The higher firm size, the more operational activities would cause greater costs. On the other hand, large companies were also more interested in maximizing their assets to meet operational funding. Therefore, firm size was able to negatively influence institutional ownership on capital structure. Suggestions for further research were to consider the calculation of institutional ownership of the company, whether including ownership of non-financial institutions, or only ownership of financial institutions. It was a concern when the shareholders of non-financial institutions were suppliers of the company. Suppliers here were not included in the category of institutional ownership, because it was said to be institutional ownership if a company helps the funding of another company through the ownership of the company's shares.

\section{References}

Arslan, O. (2008). Impact of Managerial Ownership on Capital Structure: A Survey of Turkish Firms. Corporate Ownership \& Control, 5(2), 8-14.

Ashraf, T., \& Rasool, S. (2013). Determinants of Leverage of Automobile Sector Firms Listed in Karachi Stock Exchange by Testing Packing Order Theory. Journal of Business Studies Quarterly, 4(3), 73-83.

Baum, C. F., Schaffer, M. E., \& Stillman, S. (2007). Enhanced Routines for Instrumental Variables / Generalized Method of Moments Estimation and Testing. The Stata Journal, 7(4), 465-506. 
Brailsford, T. J., Oliver, B. R., \& Pua, S. L. H. (2002). On The Relation between Ownership Structure and Capital Structure. Accounting and Finance, 42, 1-26.

Bringham, E. F., \& Houston, J. F. (2014). Fundamentals of Financial Management (14th ed.). Mason: South-Western Cengange Learning.

Chen, J., \& Strange, R. (2005). The Determinants of Capital Structure: Evidence from Chinese Listed The Determinants of Capital Structure: Evidence from Chinese Listed Companies. Economic Change and Restructring, 38, 10-35. https://doi.org/10.1007/s10644-005-4521-7

Chou, T.-K. (2015). Insider Ownership and Firm Performance: A Resource Dependence Perspective. The Journal of Applied Business Research, 31(3), 861-870.

Chung, K. H., \& Zhang, H. (2009). Corporate Governance and Institutional Ownership. Journal of Financial and Quantitative Analysis, 1-53. https://doi.org/10.1017/S0022109010000682

Cinko, M., \& Kasaboglu, O. T. (2017). A Study of The Relationship between Institusional Ownership and Capital Structure: Evidence From Turkey. Marmara Journal of Economics, 1(2), 155-170. https://doi.org/10.24954/mjecon.2017.9

Cortez, M. A., \& Susanto, S. (2012). The Determinants Of Corporate Capital Structure : Evidence From Japanese Manufacturing Companies, 11(3), 121-135.

Frank, M. Z., \& Goyal, V. K. (2003). Testing The Pecking Order Theory of Capital Structure. Journal of Financial Economics, 67, 217-248.

Gómez, G., Mena Rivas, A., \& Lizarzaburu Bolaños, E. R. (2014). The determinants of capital structure in Peru. Academia Revista Latinoamericana de Administracion, 27(3), 341-354. https://doi.org/10.1108/ARLA-01-2014-0007

Gwatidzo, A. R. T. (2013). Dynamics in capital structure determinants in South Africa. https://doi.org/10.1108/10222521211234228

Hammerstrom, G., \& Jersov, K. (2014). The Effect of Institusional Ownership on The capital Structure of Swedish Firms. Stockholm School of Economics.

Hartoyo, A. K. W., Khafid, M., \& Agustina, L. (2014). Faktor-Faktor yang mempengaruhi Struktur Modal Perusahaan Tekstil dan Garmen di BEI. Accounting Analysis Journal, 3(2), Hlm. 247-254. https://doi.org/ISSN 2252-6765.

Hayat, M., Yu, Y., Wang, M., \& Jebran, K. (2018). Impact of Managerial and Institutional Ownership on Capital Structure : A Impact of Managerial and Institutional Ownership on Capital Structure: A Comparison Between China \& USA. European Journal of Business and Management, 10(24), 69.80.

Hirdinis, M. (2019). Capital Structure and Firm Size on Firm Value Moderated by Profitability. International Journal of Economics and Business Administration, VII(I), 174-191.

Jensen, M. C., \& Meckling, W. H. (1976). Theory of the firm: managerial behavioragency and ownership structure. Journal of Financial Economics, 3, 305-360. https://doi.org/10.1016/0304-405X(76)90026-X

Joher, H., Ali, M., \& Nazrul. (2006). The Impact of Ownership Structure on Corporate Debt Policy: Two Stage Least Squwere Simultaneous Model Approach For Post Criswas Period: Evidence From Kuala Lumpur Stock Exchange. International Business \& Economics Research Journal, 5(5), 51-64.

Khafid, M., Tusyanah, T., \& Suryanto, T. (2019). Analyzing the Determinants of Financial Distress in Indonesian Mining Companies. International Journal of Economics and Business Administration, VII(4), 353-368.

Kim, B., \& Suh, J. (2010). Retained Earning and Capital Structure. JEL Classification: G32, G35.

Myers, S. C. (1984). The Capital Structure Puzzle, April.

Pindado, J., \& Torre, C. D. La. (2011). Capital Structure: New Evidence from the Ownership Structure. International Review of Finance, 11(2), 213-226. https://doi.org/10.1111/j.1468-2443.2010.01115.x

Pirzada, K., Shouldapha, M. Z. Bin, \& Wickramasinghe, D. (2015). Firm Performance, Institusional Ownership and Capital Structure: A Case of Malaysia. Procedia - Social and Behavioral Sciences 211, 170-176. https://doi.org/10.1016/j.sbspro.2015.11.025

Pratheepan, T., \& Yatiwella, W. B. (2016). The Determinants of Capital Structure: Evidence from Selected Listed 
Companies in Sri Lanka. SSRN, 8(2), 94-106. https://doi.org/10.2139/ssrn.2725792

Purba, J. T., \& Africa, L. A. (2019). The Effect of Capital Structure, Institusional Ownership, Managerial Ownership and Profitability on Company Value in Manufacturing Companies. The Indonesian Accounting Review, 9(1), 27-38.

Qiang, L. (2007). Study on the Influence of Institutional Ownership on Capital Structure of China Listed Companies. International Conference on Wireless Communications, Networking and Mobile Computing, 3981-3984.

Roshan, B., Myers, S. C., Cohen, R. D., Bradley, M., Jarrell, G. A, Kim, E. H., ... Foods, D. (2009). An Implication of the Modigliani-Miller Capital Structuring Theorems on the Relation between Equity and Debt 1. Journal of Economic Theory, 3(2), 237. https://doi.org/10.1016/0022-0531(87)90086-X

Ross, S. A. (1977). The Determination of Financial Structure: The Incentive-Signalling Approach. The Bell Journal of Economics, 8(1), 23-40. https://doi.org/10.2469/dig.v27.n1.2

Saksonova, S. (2006). The Analysis of Company's Capital and Evaluation of Factors, which Influence Creation of The Optimal Capital Structure. Journal of Business Economics and Management, VII(3), 147-153.

Shoaib, K., \& Yasushi, S. (2015). Capital Structure and Managerial Ownership : Evidence from Pakistan. BEH Business and Economic Horizons, 11(2), 131-142.

Short, H., Keasey, K., \& Duxbury, D. (2002). Capital Structure , Management Ownership and Large External Shareholders: A UK Analysis. International Journal of the Economics of Business, 9(3), 375-399. https://doi.org/10.1080/1357151021000010382

Shyu, J. (2013). Ownership Structure, Capital Structure, and Performance of Group Affiliation: Evidence from Taiwanese Group-Affiliated Firms. Managerial Finance, 39(4), 404-420. https://doi.org/10.1108/03074351311306210

Tailab, M. M. K. (2014). The Effect of Capital Structure on Profitability of Energy Americould Firms. International Journal of Business and Management Invention, 3(2), 54-61.

Wahba, H. (2014). Capital Structure, Managerial Ownership and Firm Performance: Evidence from Egypt. Journal of Management and Governance, 18(4), 1041-1061.

Wellalage, N. H., \& Locke, S. (2013). Capital Structure and its Determinants in New Zealand Firms. Journal of Business Economics and Management, 14(5), 852-866. https://doi.org/10.3846/16111699.2012.680605

Wellalage, N. H., \& Locke, S. (2015). Impact of Ownership Structure on Capital Structure of New Zealand Unlisted Firms. Journal of Small Business and Enterprise Development, 22(1), 1-23. https://doi.org/10.1108/JSBED-09-2011-0004

Zare, R., Farzanfar, F., \& Boroumand, M. (2013). Examining The Firm Age, Size and Asset Structure Effects on Financial Leverage in Tehran Stock Exchange. International Journal of Economy, Management and Social Sciences, 2(6), 256-264. 